\title{
Homosexuality and Liminality in Sodom: The Quests for Home, Fun and Justice (Gen 19:1-29)
}

\author{
Cephas Tushima (Jos ECWA Theological Seminary-JETS \& \\ UNIVERSITY OF SOUTH AFrICA)
}

\begin{abstract}
This essay explores the first segment of the Lot sub-narrative of the Abraham cycle (Gen 11:27-25:10). The study adopts a narrative close reading approach and canonical theological hermeneutical framework in its reading strategies (with the canon's reception history undergirding its plausibility structures), aiming ultimately at unfolding the world of possibilities of being-in-the-world in the text, particularly from an ethical standpoint. The study shows Lot, enmeshed in his sense of marginality from YHWH's repeated covenantal promises of progeny to Abraham, ditch time-tested tradition and embark on a quest for freedom and a home of his own, consequently, assuming significance and security in Sodom (where he sat on the city council at the gate). His initial assumed marginality in Abraham's home attains reality in Sodom, where the Sodomites desirous of 'having fun' with Lot's angelic guests (who were on a search for justice) reprimands Lot, a mere immigrant-in their view-for his audacity to rebuke them. The visitation of YHWH's justice on Sodom renders the self-serving Lot homeless, driving him to ultimate marginality, as he inhabits the liminal space of an incestuous cave dweller. A theologico-ethical appropriation of the narrative draws attention, first, to the temptation often to be so caring to outsiders and yet be so unkind to those closest to us (like Lot). Second, tradition is a stabilising force in society and jettisoning it unnecessarily creates cascading disequilibria. Third, alienation from God is the grand source of all liminality. Fourth, inordinate desires lead to choices that bring about a breakdown in the social order. Fifth, like Lot, we need to catch heaven's heartbeat for the oppressed and become voices for their justice in our time.
\end{abstract}

KEYWORDS: Genesis, Lot, Abraham, Sodom, narrative criticism, intertextuality, immigrants, homosexuality, justice, biblical ethics

\footnotetext{
Submitted:17/02/2021; peer-reviewed: 21/04/2021; accepted: 05/05/2021. Cephas Tushima, "Homosexuality and Liminality in Sodom: The Quests for Home, Fun and Justice (Gen 19:1-29)," Old Testament Essays 34 no. 1 (2021): 68 - 88. DOI: https://doi.org/10.17159/2312-3621/2021/v34n1a6.
} 


\section{A INTRODUCTION}

Biblical narrative texts record several manifestations of sexual passion with wide-ranging negative implications. Gen 19 , along with others, form part of a larger study I am working on with a focus on issues of sex, politics and their concomitant perils in Hebrew biblical narratives. In all good literature, the opening pages provide guideposts for understanding what ensues, the same holds for biblical literature. Thus, the prefatory positioning of Genesis in the larger history of Israel (Genesis to Kings) is indicative of how the rest of the history reads, ${ }^{1}$ and in this regard, the primeval history is indeed critical. In an earlier study of Gen 3, I identified five themes arising from human actions with damaging consequences. These themes are desire (for this paper, sexual passion), alterity, power play (or politics), peril (usually resulting in bodily harm, often of community-wide proportions), and the characterisation of God (particularly, divine response to human deviant conduct). ${ }^{2}$ I will be employing these themes as heuristic tools in a narrative close reading of this passage to tease out its ethical implications. In doing this, I will pay attention to the intertextual connections of Gen 18-19 to other texts both in Genesis and more broadly in the narratives of Israel's history.

\section{B HERMENEUTICAL FRAMEWORK}

With the great influence of the biblical text on Western civilisation (until recently), the story of Sodom and Gomorrah is one of the epic stories that had infused the common consciousness of the Western mind for generations. So common is the knowledge of the story from ancient times that even the Greek and Latin historians, Strabo and Tacitus, recorded it. ${ }^{3}$ At its core, however, it is a biblical text, which will be read in this essay as part of the Christian Scriptures. In doing this, I will be following in the tradition of modern Protestant scholarship that reached its maturation in the works of Karl Barth, ${ }^{4}$ but is more recently well-articulated in Brevard S. Childs and has been continued by others like R.W.L. Moberly. Childs, on his approach to biblical interpretation, writes,

I do not come to the Old Testament to learn about someone else's God, but about the God we confess... I do not approach some ancient concept, some mythological construct akin to Zeus or Moloch, but our God, our Father... I do not come to the Old Testament to be

1 On the importance of Genesis as the starting point of research in biblical studies, see David M. Carr, Reading the Fractures of Genesis: Historical and Literary Approaches (Louisville: Westminster John Knox, 1996), 3-4.

2 Cephas Tushima, "The Paradigmatic Role of Genesis 3 for Reading Biblical Narratives about Desire," Unio cum Christo 5/1 (April 2019): 87-103.

3 Nahum M. Sarna, Understanding Genesis (New York: Schoken Books, 1966), 138.

4 Karl Barth, Anselm. Fides Quaerens Intellectum: Anselm's Proof in the Existence of God in the Context of His Theological Scheme (London: SCM Press, 1960) as well as his other works. 
informed about some strange religious phenomenon, but in faith I strive for knowledge as I seek to understand ourselves in the light of God's self-disclosure. In the context of the Church's scripture I seek to be pointed to our God who has made himself known, is making himself known, and will make himself known. ${ }^{5}$

Childs' statement stands in the Augustinian tradition well captured in Anselm's statement of "faith seeking understanding." Echoing the same sentiments, Moberly holds that Genesis is to be read as "part of the authoritative scriptures of synagogue and church, wherein there has been an unbroken history through the centuries of living with the text in a variety of ways, not least its incorporation into regular worship, both through reading aloud and in liturgical texts." Moberly further states that the reception history of the biblical text furnishes it with a plausibility structure, and within the communities of faith, it is read theologically, implicit in which is the convergence of the horizons of the text, the canonical context and the life context of the reading communities. ${ }^{7}$

It is this theological approach of reading the biblical text as Scripture (with its reception history), combined with an anticipation of its unveiling of a world of possibilities of being-in-the-world, that I follow in this essay. This is not to be understood as a discountenancing of historical-critical studies. To the contrary, we acknowledge the value, and build upon the results of such works. In this essay, for example, we assume a conscious redaction and shaping of the corpus from Genesis to Kings by priestly redactors, which places the final redaction of the work in the sixth or fifth century BCE. ${ }^{8}$

\section{LITERARY CONTEXT OF GEN 19:1-29}

The immediate context of Gen 19:1-29 is Gen 18-19, which narrates the destruction of Sodom and its environs and the effect of the incident on Lot's family. However, the passage has to be understood in an ever-widening concentric contextual circles, the next being that of the Abraham narrative cycle

5 Brevard S. Childs, Old Testament in a Canonical Context (London: SCM, 1985), 28-29.

6 R. W. L. Moberly, The Theology of the Book of Exodus (New York: Cambridge University Press, 2009), 6.

7 Moberly, The Theology of the Book of Exodus, 17.

8 Yitzhak (Itzik) Peleg, "Was Lot a Good Host? Was Lot Saved from Sodom as a Reward for His Hospitality?" in Universalism and Particularism at Sodom and Gomorrah: Essays in Memory of Ron Pirson (ed. Diana Lipton; Atlanta: Society of Biblical Literature, 2012),129-56. See also Gerhard von Rad, Genesis: A Commentary (London: SCM Press, 1972). 
(Gen 11:27-25:10). Beyond this is the context of the Torah, then, the History of Israel (i.e., Genesis to Kings) ${ }^{9}$ and ultimately the entire Hebrew Bible.

The immediate context of our text can be divided into three main stories. the first entails the announcement of the anticipated judgment of Sodom (with the visit to Abraham, the prediction of Sarah's pregnancy, and Abraham's intercessions for Sodom [with Lot in view], ch. 18). The second is about the arrival of the judgment of Sodom (through the arrival of the angels, the deliverance of Lot, and the obliteration of Sodom, 19:1-29); while the third has to do with the effect of the judgment on Lot and his family (19:30-38). The major theme of this narrative is "righteousness and justice" (תצדקה ומשפ). The term משפת consists in either the laying out of the ground rules for societal harmony and interpersonal engagement and/or adjudication between disputing parties toward ascertaining culpability or otherwise for exculpation and/or dispensing of the necessary and sufficient sanctions. On the other hand, צדקה deals with the acknowledgement of extant societal norms for just order and their observances especially in interpersonal relationships and their aggregate impact for society at large. These terms are often used as hendiadys in the Hebrew Bible with expectations for compliance with conventional or customary codes of conduct for healthy and equitable relations. This is in the sense in which they are used in this study.

In English versions of the Bible, משפת is often translated as "justice" or "judgment." As Abraham's heavenly guests readied for departure, YHWH deliberates the propriety of revealing Sodom's impending judgment to Abraham, and finds justification for it in Abraham's election and his commitment to raise a godly progeny that would keep the way of $\mathrm{YHWH}$, which is doing "righteousness and justice" (צדקה ומשפט, 18:19). The rest of the story becomes an outworking of the theme. First, YHWH tells of the great outcry against Sodom and his journey there to ascertain its culpability, the implication being that they would get what they deserve. Second, Abraham questions God, the judge of all the earth, on the propriety of collateral punishment and instead proposes

9 In the History of Israel, the similarity of Judg 19 to Gen 19 is not lost on readers. Niditch, commenting on Judg 19, notes, "As in Genesis 19, the aggressive and violent demands of the mob involve homosexual rape (Jud 19:22)." Susan Niditch, Judges: A Commentary (The Old Testament Library; Louisville: Westminster John Knox Press, 2008), 193. Similarly, in comparing Gen 19 with Judg 19, Schneider states, "There have already been parallels with the story of Lot in Sodom, and the reference to knowing the man sexually firmly ties the two stories together... In both cases the male residents of the town wanted to know the male visitors sexually (Gen 19:5)" Tammi J. Schneider Judges (Berit Olam Studies in Hebrew Narrative and Poetry; Collegeville: The Liturgical Press, 2000), 261. We could say more about the similarities between Gen 19 and Judg 19, but that discussion will have to wait for another day due to space limitation. 
collateral redemption, whereby the wicked are spared because of the righteous. The centrality of the theme of righteousness and justice in this narrative emerges in Abraham's advocacy for the suppositious righteous in Sodom (18:18-31), as evident in the frequency of occurrence of the word roots, צדק (7x in vv. 19, 23, 24, 25, 26) and משפת (3x in vv. 19, 25). Note the preponderance of צדק (the measure of rightness of relationship between people) over משפת (the establishment or enforcement of customary norm). Third, the events that unfold in Sodom, confirm the justice of its judgment. Fourth, the conduct of Abraham and Lot as hosts manifests their righteousness. Fifth, the incestuous end of Lot's life (19:30-38) raises doubts about his righteousness, yet his rescue shows that he is righteous, per the deal YHWH struck with Abraham - he would not sweep (ספ,18:23; cf. 19:15,17) away the righteous with the wicked. This review of this immediate context invites a closer look at the place of our text within the Abraham tradition.

Lot appears in the biblical text at the same time with Abraham in a genealogical note on their family line (11:27-31). Two critical pieces of information are volunteered about them at this point. Lot's father is dead and he is being cared for by his grandfather; and Abraham's wife, Sarah, is barren. Within the context of their time, there is a less than veiled hint that Lot was intended to be Abraham's heir. ${ }^{10}$ This explains why Abraham took Lot under his wings anywhere he went. It is also telling that Abraham never complained of childlessness (with a proposal of Eliezer of Damascus being his heir, 15:2-3) ${ }^{11}$ neither did Sarah come up with the idea of a child from Hagar (Gen 16) until Lot had permanently severed ties with Abraham.

After their return from Egypt (13:1-2), the wealth they had acquired through Abraham's wife-as-sister ruse ruptured their harmony and they had to part ways (13:6-7). Lot's non-deferential attitude to his uncle in his grasping the

10 For more on this, see William John Lyons, "The Eternal Liminality of Lot: Paying the Price of Opposing the Particular in the Sodom Narrative," in Universalism and Particularism at Sodom and Gomorrah: Essays in Memory of Ron Pirson (ed. Diana Lipton; Atlanta: Society of Biblical Literature, 2012), 3-15. See also Naomi Steinberg, Kinship and Marriage in Genesis: A Household Economics Perspective (Minneapolis: Augsburg Fortress, 1993), 48; Mark G. Brett, Genesis (London: Routledge, 2000), 56; David W. Cotter, Genesis (Collegeville: Liturgical Press, 2003), 90; and Nachman Levine, "Sarah/Sodom: Birth, Destruction, and Synchronic Transaction," JSOT 31 (2006): 140.

11 Note that in Gen 15:3, Abram further explains to God that because of God's failure to give a child, a member of his household would inherent him. When Lot was in view, he was still family (as a blood relative), but it became too painful to Abraham when it dawned on him that a complete outsider (a servant) would become his heir. 
apparently better land widened the gap between the two relatives (13:8-12). ${ }^{12}$ Indeed, the starting point was his reticence to restraining his herdsmen (as the younger) from bickering with those of his uncle. Lot's conduct could be explained on two counts. First, he still had nostalgia for the good life he had in Egypt, hence, his attraction to Sodom, "a land that superficially resembles not only the Garden of Eden but the land of Egypt."13 Second, as any young adult tired of depending on his or her parents, seeking to break loose from the parents' apron strings, Lot shows signs of restiveness. While his age at the death of his father is not given (neither the whereabouts of his mother), we could safely surmise that he was tender in age. From that time, he had been dependent, first upon his grandfather, and later his uncle. At the same time, the promises of YHWH to Abraham persistently told of progeny from Abram's loins. Thus, while Abraham always cared for Lot, there were abiding airs of marginality and liminality about him. ${ }^{14}$

Thus, Lot seized the first opportunity that came his way to break free from the particularity of tribal ways and sought to embrace cosmopolitan life, first, by pitching his tent near Sodom, notwithstanding its reputation for wickedness (13:10-13). Second, after being rescued by Abraham from their Mesopotamian attackers (Gen 14), Lot probably profited from the reputation of being the nephew of the most powerful warlord in the region, thereby, not just gaining property in the city, but becoming one of its leading men as a member of Sodom's magisterium (from his sitting at the gate) ${ }^{15}$. However, even in Sodom, Lot would be plagued by his alterity (cf. Gen 19: 9) until he would reach his ultimate liminality, vanishing in oblivion as an incestuous grandfather in a mountain cave.

The section of the Abraham tradition in which the sub-narrative of Lot is embedded is held together by several literary factors. First, Abraham is the hero of the story and everything serves to build his image. Consequently, the more closely aligned with him the better off you would be and the obverse is true (cf.

12 On this, Pace notes, "Lot's dispute with Abraham over division of the land yields the first glimpse of his self-serving nature and places his [later] indifference toward his daughters in context." Sharon Jeansonne Pace, The Women of Genesis: From Sarah to Potiphar's Wife (Minneapolis: Fortress, 1990), 4.

13 Goshen Harper, Legal Frictions: Law, Narrative, and Identity Politics in Biblical Israel (New York: Peter Lang, 2010), 171.

14 Cf. Lyons, "The Eternal Liminality of Lot," 11.

15 For similar views see, Bruce K. Waltke and Cathi J. Fredericks, Genesis: A Commentary (Grand Rapids: Zondervan, 2001), 275; and Gordon J. Wenham, Genesis 16-50 (Word Biblical Commentary, Vol. 2; Dallas: Word Books, 1974), 54. For a contrary opinion (albeit, one that borders on mere fancy), see Scott Morschauser, "“Hospitality,' Hostiles and Hostages: On the Legal Background to Genesis 19.1-9," JSOT 27/4 (2003): 461-485. 
12:3). If we take the issue of laughing at news as an example, Abraham laughed cynically when told he would have a son, yet rather than being censored, he received YHWH's confirmation of the promise with the son's name (17:17-19). When Sarah laughed at the same news, YHWH reprimanded her (18:12-15). There was divine silence at the mockery of Lot's sons-in-law (19:14), after he warned them of the coming doom, and they were swept away with the rest of the city. Ishmael was booted out of the family for mocking Isaac (21:1-14). All the ישב אחק ("laugh/mock"). Second, is the terms come from the same root ("to sit/dwell"). Between Gen 11:27 and 19:38, ישב appears only in the discourses that involve Lot, at either discourse terminal or initial points (11:31; $13: 6-7,12 ; 14: 12 ; 13: 12 ; 18: 1 ; 19: 1,29-30)$. The constant movement and settling down highlight the sense of dislocation, marginality and liminality of Lot.

There are several intertextual links between Gen 18-19 and other texts in the Torah but suffice to mention just two. The flood narrative, for one, has striking parallels with the Sodom story. The parallels include the exceeding wickedness of the people in both situations (6:5; 18:20; cf. 13:13). Besides, there are insinuations of abnormal sexual relations associated with both eras (6:1-2; 19:4-8). The biblical authors use not just the same word (שחת), but the same stems, the same grammatical forms and order-first, a hiphil participle and then a piel infinitive construct $(6: 13,17 ; 19: 13)$ - to write about the fates that awaited the doomed populations. ${ }^{16}$ This points to the irredeemable character of the perverse Sodom.

Calum Carmichael regards the Sodom narrative (Gen 18-19) as the background for several priestly ${ }^{17}$ and Deuteronomistic legislations. Examples of these include the prohibition of homosexuality (Lev 18:22; 20:13; cf. Gen 19:5); the first prohibition in incest laws (Lev 18:7; cf. Gen 19:32-35); and the exclusion of Moabites and Ammonites from YHWH's assembly (Deut 23:2; cf. Gen 19:30-38). These all point to the necessity of reading the passage within its contexts.

\section{$1 \quad$ Literary Analysis of Genesis 19:1-29}

Our text is clearly parenthesised with the verb ישב ("to sit" or "to dwell"). Verse 1 opens with Lot sitting at the gate of Sodom (a different setting from Mamre, from where the angels came after visiting Abraham), and verse 29 closes the unit with a flashback reference to the just destroyed cities in which Lot previously dwelt. Verse 30 begins a new literary unit (within the Lot sub-narrative) with Lot

16 See Wenham, Genesis 16-50, 56.

17 Calum Carmichael, "Legal and Ethical Reflections on Genesis 18 and 19," in Universalism and Particularism at Sodom and Gomorrah: Essays in Memory of Ron Pirson (ed. Diana Lipton; Atlanta: Society of Biblical Literature, 2012), 101-111. 
dwelling in a cave in the hills with his daughters. In between these two verses, Lot remains the focus of the narrative. The divine visitors also serve to hold the story together, as they appear in all its sections. One observes their alternate identifications in the narrative, as they are referred to as men by the narrator, Lot and the Sodomites (vv. 1, 5, 10, 16); men of God by Lot (v. 8) ${ }^{18}$, angels by the narrator (vv. 1, 5) and, finally, are addressed as divine by Lot (v. 18) ${ }^{19}$. This progression in the status of the identification of the guests reveals the gradual improvement of the perception that Lot had of who his guests (though the narrator seems to cast him as a buffoon). ${ }^{20}$

\section{A LAVISH WELCOME FOR UNKNOWN GUESTS (GEN 19:1-3)}

The Sodom narrative has a beautifully laid out plot that opens with the setting (v. 1). It was evening time, when the angels arrived at the city gate where Lot was sitting. ${ }^{21}$ Lot's enthusiastic welcome of the visitors sets the narrative rolling. The strikingly similar beginnings of Gen 18 and 19 ineluctably invite comparison between them. Broadly speaking, commentators are divided between those who see Lot's hospitality as the same as Abraham's (18:1-9), and in that regard he is righteous, his faults notwithstanding, ${ }^{22}$ and those who see it as austeresignifying Lot's flawed character. ${ }^{23}$

18 It is perplexing that this epithet, significant as it is, is not captured in any English translation, and it also receives little attention from commentators.

19 There is a suggestion that YHWH resurfaces, but we will return to this later.

20 Indeed, Waltke and Fredericks suggest that the narrator's alternate identification of the angels is intentional. This is so that his audience would "make connection between the phenomenological and the theological. As narrator-historian he describes them from the earthly viewpoint: they appear to be 'men' (see 18:2, 8; 19:16); as narrator-prophet he describes them from the heavenly perspective: they are divine messengers" (Genesis, 274-275).

21 A noun-clause with participial predicate conjoined by a waw-copulative to a verbalclause signifies a contemporaneous state/action (cf. Gesenius $\S 141 . e$ ).

22 See Laurence A. Turner, Genesis (Second Edition; Sheffield: Sheffield Phoenix Press, 2009), 83; and Harper, Legal Frictions, 182.

23 Among those who view Lot's hospitality negatively, Pace takes her critique to the level of absurdity. Along with other things, she points out that Abraham ran to meet the guest, Lot only stood; Abraham's speech is very obsequious, Lot's had no such oriental deference; Lot offered the guess only lodging and no food (even though he later gave them food); Abraham's family was involved (wife and servant), not so with Lot; the use of פצר smacks of Lot's endangerment of the guests (The Women of Genesis, 3435).

Pace's critique is ridiculous and shows either a lack of appreciation of Near Eastern cultures and the Hebrew language or it is purely being blinded by an agenda driven scholarship. For example, if someone is sitting at a gate and a guest walks into the gate, there is no better way to welcome the guest than to stand. Besides, Lot's language is no 
One of Pace's unfavourable portrayal of Lot is that while Abraham's food was elaborate (18:6-8), Lot's was just unleavened bread (19:3). Nothing could be further from the truth. Indeed, one may surmise that Lot's food was more elaborate (as an urbanite) than Abraham's, hence, less need to list the items on the menu; it is simply reported that he "made a feast" (עשה משתה) for the guests. For Wenham, "עשה משתה describes the banquets given on special occasions, e.g., the weaning of Isaac (21:8), weddings (29:22; Judg 14:10), and royal entertainment (40:20; $1 \mathrm{Kgs} 3: 15) . " 24$ On the paucity of Lot's meal because of the unleavened bread, Harper argues that it rather anticipates the Passover and it is an encouragement to welcome the Ammonites and Moabites, serving also as a counter-polemic against latter exclusivist priestly and Deuteronomistic tendencies of the type recorded in Ezra-Nehemiah. ${ }^{25}$ Whatever our views of Lot on other counts, as far as his entertaining of these total strangers is concerned, he cannot be faulted, and in the Hebrew Bible this is a manifestation of righteous conduct toward strangers (the "other"), who, as the events will unfold, were very vulnerable, at least from a human perspective.

\section{E DESIRE-DRIVEN RIOT IN SODOM (GEN 19:4-11)}

The storyline progresses to rising tension/conflict as the townsmen of Sodom converge on the home of Lot (the immigrant). The story is told with dexterity using scenic dialogues interspersed with little narration. Overall, it forms the following thematic parallelism:

A Citizens' onslaught on aliens in an immigrant's house: Verbal aggression (vv. 4-5)

B Immigrant's response: physical and verbal actions (Draws closer, door shut, and appeals) (vv. 6-8)

$\mathrm{A}^{\prime} \quad$ Citizens' response targeting immigrant: verbal and physical assaults (vv. 9)

B' Aliens' response: Double physical action directed toward the immigrant and the citizens (Draw immigrant in, door shut, and citizens blinded) (vv. 10-11).

less obsequious than Abraham's, typified by his frequent use of the particle of entreaty, נא (lit., "I beg you" or "please"). Indeed, Lot's speech, by ANE standard, is more deferential as he makes no use of the first-person pronoun at all in addressing the guests, while Abraham did. In traditional societies, the invitation to rest (wash the feet in our text), drink water, or spend the night is a total package, including food as well (cf. Gen 24:31-33).

24 Gordon J. Wenham, Genesis 16-50. Word Biblical Commentary, Vol. 2. (Dallas: Word Books, 1974), 54.

25 Harper, Legal Frictions, 171-183. 
One feature of this unit is the shutting of the door, which functions powerfully to convey the power play between the three main groups of actants in the narrative, namely the bona fide citizens (the Sodomites), the cosmopolitan immigrant who assumes leadership in the city (Lot), and the aliens (the angels). In Line A in the parallelism, the citizens converge outside Lot's house. Their primary action at this point is verbal to Lot (the resident immigrant) but directed toward the non-resident aliens. This is followed in Line B by the twofold actions of the immigrant Lot, who went out to the townsmen, shut his door (physical action) and then verbally appeals to them to espouse higher moral grounds. In Line A', the reaction of the Sodomites to Lot's moral pedantry was to assault him verbally (highlighting his alterity as an immigrant) as well as physically. Outside the door lies trouble. Finally, in B', the visitors stepped into the fray. In their response, eschewing verbal engagement at this point (sign of coming peril), they mimicked the physical action of each of the two previous actants. They drew Lot (who had previously gone out) back into the house and shut the door, ensuring safety for everyone, and then assaulted the sight of the Sodomites, who had earlier physically assaulted Lot.

This unit and the previous one are closely related, forming one episodethe arrival of the angels and their treatment (both by Lot and the Sodomites). A verbal leitwort running through the two scenes is ("to come," "to go," and in the hiphil stem, "to bring"). The outcry against Sodom's great sin had come (בוא) before YHWH (18:19), who sent his angels to go (בוא) and confirm the news. The angels came (בוא) to Sodom (19:1) and ultimately to (בוא) Lot's house to spend the night (19:3). In the present scene, the men of the city encircled Lot's house, demanding that the angels be brought (בוא) out to them (19:5), but Lot went (בוא) out to them instead. Instead of giving out his guests, Lot offered to bring בוא) out his virgin daughters to the men. The angry Sodomites ranted that Lot came (בוא) to sojourn but has now become a judge; and as Lot's life was threatened, the angels brought (בוא) him back into the house (19:10). All the various movements, triggered by the initial ascent of the evil report to YHWH, served to prove the culpability of Sodom and justice meant retribution.

\section{Indigene-Immigrant Polemics and Justice (Gen 19:4-9)}

This scene opens with the uninvited visit of Sodom's townsmen to Lot's house. The narrator says they were encircling the house (the implication of סבב in the niphal stem v. 4), presaging their aimless wandering around the house when they would be blinded later by the angels. YHWH had told Abraham he would be visiting Sodom to confirm its wickedness. Here, the narrator relates the total corruption of Sodom in the way he reports the visit to Lot's house in this parallelistic structure below. Put differently, there are four descriptor subject phrases with accent on the domiciliary city (the men of Sodom) and the breadth of the people involved (all the people: young and old). The verbal phrase specifies their activity (encircling Lot's house) and the prepositional locative 
adverbial phrase specified where they came from (every end of the city). In other words, the entire city was represented and no part was left behind.

ואנשי העיר אנשי סדם

The men of the city, the men of Sodom

נסבו על־הבית

milled around the house

מנער ועד־זקן כל־העם

from the young to the old, all the people

מקצה
Two apposite descriptor subject phrases

Verbal phrase with locus of action

Two descriptor phrases

(prepositional phrases and an

appositional phrase)

Prepositional adverbial phrase of origin

from the end of the city.

The assembled men called out to Lot and demanded that he hands over to them the men visiting him, so that they might "know" (ידע (ידע (2) them. The verb in this passage has become the basis of much speculative (albeit, ideologically driven) interpretations. There are those who take ידע for the simple meaning of "cognition." Dianne Bergen admits that the sin of Sodom has long been held to be homosexuality, yet argues that it was inhospitality and gang rape, and that Lot's offer of his daughters makes homosexuality irrelevant. ${ }^{26}$ Bergen anachronistically critiques an ancient literature based on contemporary mind-set. What undercuts Bergen's argument is the very offer of Lot's daughters. If rape in general were the problem, Lot's offer of his own daughters would make no sense whatsoever. It was rather the idea of men having sex with other men that offended Lot's morality, resulting in his reprehensible offer of his daughters for gang rape, to protect the patriarchal conception of male dignity.

Von Rad posits that sexual aberration was in vogue in the aged civilisation of the ancient Near East and with much sophistry places Sodom's fault on their inhospitable character and a litany of other sins enumerated by the latter prophets. ${ }^{27}$ Noort minimises the significant role of the sexual theme in this text, claiming it arose only in the later history of the narrative's reception. Rather, harping on gang rape and the inhospitality of Sodom, he writes, "When Genesis 19 speaks of rape and the violation of the duty of hospitality, both homosexual and heterosexual relations are viewed as being perverted, the latter being evident from Lot's offering of his two daughters to the mob." 28 Scott Morschauser understands the whole narrative in the mould of national security and proposes that the townsmen wanted to have the guests for interrogation but Lot who was a gateman sought to save his honour by giving his daughters as hostages (not to

26 Dianne Bergen, Genesis: In the Beginning (Liturgical Press, 2013), 87-88.

27 Von Rad, Genesis, 217-218.

28 Noort, "For the Sake of Righteousness," 4. 
be raped) until the morning when the men would sneak out of town. ${ }^{29}$ If Morschauser is correct, Lot's statement that his daughters did not know any man will be utterly meaningless.

Conversely, others continue to hold on to the traditional view. Indeed, reception history points to homosexuality as the grievous offence of Sodom. As pointed out above, the prohibition of homosexuality in the Torah appears to have been a response to Sodom. In the David-Saul polemic, the Deuteronomist clearly wanted his audience to perceive the Benjaminites as lurid homosexuals like the Sodomites (Judg 19). The New Testament author of Jude also understood Sodom's sin to be homosexuality (v. 7). Other early interpreters held the same position as well (cf. Pseudo-Jonathan, Gen 19:5; T. Benjamin 9:1; Philo, Abr. 135-37; Josephus, Ant. 200). ${ }^{30}$

Ultimately, understanding the text in its literary context is the best approach to take. Carmichael takes עי עי (vv. 5) as "iniquitous homosexual craving," and states further, "At all times, homosexuality is a minority activity. Yet in this narrative, the entire population is involved, minus the women who, from the narrative's perspective, do not count." ${ }^{31}$ Waltke and Fredericks, who equating ידע with "sex," state that, "Homosexuality is a capital offense in the Old Testament (Lev 18:22; 20:13). The sin of Sodom's act is presumably the worst sort of sexual offense: homosexual gang rape (cf. Judg 19; Jude 1:7)." ${ }^{32}$ Indeed, the townsmen's request to "know" the guests and Lot's offer of his daughters who had not known any man (Gen 19:9), as he states, draw a natural connection. ${ }^{33}$

In response to this bizarre proposal, Lot steps out of the house to address the menace. He secures the door to protect his guests and family inside, and then offers a palliative appeal to the townsmen not to act wickedly (אל־נא אהי תרעו, vas, v. 6). Lot calls this requested abnormal coitus, acting wickedly ( (רערע). Joseph, similarly, called adultery (another abnormality) great wickedness (רע) and $\sin (\pi / \sqrt{ })$ against God (Gen 39:9). Genesis 13:13 says the men of Sodom were

29 Morschauser, "'Hospitality,' Hostiles and Hostages," 461-485. See also Megan Warner, "Keeping the Way of YHWH: Righteousness and Justice in Genesis 18-19," in Universalism and Particularism at Sodom and Gomorrah (ed. Diana Lipton; Atlanta: Society of Biblical Literature, 2012),113-125.

30 Peleg, "Was Lot a Good Host?," 133-135, cites a number of medieval rabbis who understood Sodom's sin to be homosexuality.

31 Carmichael, "Legal and Ethical Reflections on Gen 18 and 19," 101-104. See also

E. A. Speiser, Genesis: Introduction, Translation, and Notes (The Anchor Bible; Garden City: Doubleday, 1964), 139.

32 Waltke and Fredericks, Genesis, 276. See also Wenham, Genesis 16-50, 55.

33 For the use of the verb "to know" as a euphemism for sexual relations, see Gen 4:1, 17,$25 ; 24: 16$. 
great wicked sinners (a hendiadys with חתתא + רעע easy to see with the Tannaim that the ידע of the Sodomites meant homosexual copulation, hence, Lot's outrage. ${ }^{34}$ It was in view of this request that Lot made the inexcusable offer of his virgin daughters to the Sodomites.

Besides failing in his paternal responsibility, Lot was occasioning the occurrence of three evils. First, he was arranging for the rape of virgins, an evil that offends Israelite ethos (cf. Gen 34:7; 2 Sam 13:12); second, gang rape, for which Israel embarked on civil war (Judg 19); and third, betrayal of trust, as he was offering women pledged in marriage to other men for rape (Gen 19:14; cf. Lev 18:20; 20:10; Deut 22:13-24). A possible explanation for Lot's strange offer of his daughters may be found in his improving understanding of his guests. In his appeal to the townsmen, he now refers to them as "men of God" (אנישים האל) the first time this epithet is used in the Bible — who deserve better treatment, even at any cost.

Lot's alternate rape objects little assuaged the desires of the Sodomites, at which point they launched verbal tirades and physical assault on Lot. They brought up Lot's immigrant status to challenge his position of privilege in the city. They were now hell-bent on having him as their partner that night ("we will deal more wickedly with you than with them," v. 9). It is at this point that the irony of the tales unfolds. Lot who set out to help the angels was now the one they would be helping. Thus, the quest for "righteousness and justice" in Sodom that was hinted at in Gen 18 is now concluded - the fact of the case was established: all of Sodom was guilty as charged and there was only one righteous man (even though a compromised one), Lot, who still endeavoured to maintain rightness in his relations with other people.

\section{Help for the Helpless "Other" (10-11)}

The age-old saying that you reap what you sow comes true at this point in the narrative. Since Lot had determined to seek the welfare of his guests, whom the townsmen had sought to take undue advantage of because of their alterity, it was his turn now to be delivered from the wicked grasp of the same men, who found his advocacy for justice a pestilent nuisance due to his immigrant status. In the reversal of roles, just as Lot had gone out and shut the door (v. 6) to seek his guests' safety (though at his own detriment), they in turn now drew him in to safety (v. 10) and shut the door. Similarly, the Sodomites had their own sarcastic fate reversal, from encircling Lot's house out of excitement for their anticipated fun of the night to a confused exhausting search for the door of Lot's house after the angelic guests struck them with blindness (v. 11).

34 Talmud, b. Sahn, 109a-b. 
This scene becomes a hint to the partial answer to Abraham's intercession; though Sodom will not be spared, the righteous (even a compromised one like Lot) will not be swept away with the wicked. One bad omen for the city is the non-engagement of the men of Sodom by the divine actants. At the start of the narrative (Gen 18), there was adversarial divine visitation, which still leaves a door of hope (which has now been opened to Lot, who is positively engaged by the heavenly visitors). However, for the rest of Sodom, divine silence manifest in the non-engagement spells doom.

\section{F NOT HOME YET: ESCAPE FOR YOUR LIFE (GEN 19:12-22).}

Restless as Lot had been in his marginal and liminal life, rest was not in sight for him yet. Though he considered Sodom home, Sodom did not consider him one of its own; and with its impending eventual doom, his heavenly guests would forcefully eject him out of the city. This unit functions as a pre-peak episode in the plot of this sub-narrative, which consists of two major scenes - the warning to flee the city (19:12-14) and the expulsion from the city (19:15-22). These two scenes are clearly marked with distinct leitworts. The key words in the first scene (19:12-14) are "get out" (יצא), "place," (מקם), and "destroy" (שהת)), each of them occurring three times in the scene. The message is clear and insistent, "Flee this place that will soon be destroyed." In the second scene, the leitwort clearly is "escape" (מלת), occurring five times plus its synonym "flee," (נוס) making it six times. The message is stridently urgent, "escape to safety so you will not be swept away (ספה, vv. 15, 17) with the wicked city, as YHWH had promised Abraham' (18:23-26, where ספה ס ס ס 2x).

\section{Quit Notice to Lot and Family (Gen 19:12-14)}

This first scene consists of two warnings to leave the city that amount to the quit notice given to Lot and his family. The first warning was given in Lot's house; the angels counselled him to get out of the city before tragedy befell it. They spoke plainly, specifying all the relationships that could profit from collateral redemption, in accordance with Abraham's prayers-sons-in-law, sons, daughters, and everyone else he has in the city. One observes that while all the closer filial relationships are mentioned, there is no mention of wife. Perhaps, it could be assumed that a man would naturally flee danger with his wife first before any other relations. However, it could be an adumbration of the impending disastrous end of Lot's wife. The second warning occurs in the city. The angels had asked Lot if he had other relatives in the city and Lot, following the cue of the angels, called on his sons-in-law to get them out of town because of the judgment that hung over the city. However, the warning was ignored, since in their perspective (בעיני), Lot was a mere jester. 
In the Bible, acting according one's own perspective is often antithetical to fulfilling the divine will. Regarding this biblical motif, Cephas T. A. Tushima notes,

טוב בעיני ('right in the eyes of') or its synonym ישר בעיני (') 'ישי ('good in the eyes of') is often used to indicate a personal preference and has the connotation of choosing one's way rather than God's way (cf. Deut 12:8; Judg 17:6; 21:25; Prov 21:2). The same expression is used later in 1 Sam 29:6, 9 and 2 Sam 3:19, 36 (cf. Num 24:1; Prov $3: 4$; Mal 2:17, where the reference is directly to what is pleasing to God). ${ }^{35}$

Tushima demonstrates that whenever people do things to suit their perspectives or those of other humans, it portends death ultimately (cf. 2 Sam 3:13-17, 21, 36). ${ }^{36}$ In our text, Lot first proposed to give his daughters to the Sodomites to be used as it seemed good in the Sodomites' eyes (כטוב בעיניכמ, v. 8), as a way of satisfying their base sensual desires. In this scene, Lot's sons-inlaw, not understanding the issues from God's perspective, viewed Lot's urgent call to evacuate the city as baseless. Thus, from their point of view, he was no more than a clown (v. 14). The entire range of Sodomite population also was acting on their own and thus faced the fate of those who act to please themselves.

In filling the gaps occasioned by the non-reportage of Lot's discourse with his wife and daughters about fleeing the city, Pace implicitly accuses him of misogyny,

He ignores his own daughters, even though the angels specifically command him to save them. The narrator provides a gap that prompts the reader to ask whether it would have been likely for Lot to have informed his wife. Given his previous behavior, the reader is led to conclude that Lot probably remained silent. ${ }^{37}$

Such a stance is unwarranted. First, the family was with Lot in his tent as the angels discussed with him and so it would be taken for granted that they were aware. Besides, while addressing the mention of Lot at the gate (without the mention of other city council members), Wenham raises a point about the selectivity principle of biblical authors (which is true also of modern historiography), which applies here as well. He writes, "It is characteristic of Bible storytelling to focus on the main actors and to omit reference to the other figures of less consequence who are present but passive." 38 Another gap the narrator leaves at this point is the reason Lot's sons-in-law did not believe him.

35 Cephas Tushima, The Fate of Saul's Progeny in the Reign of David (Portland: Pickwick, 2011), 161.

36 Tushima, The Fate of Saul's Progeny, 139.

37 Pace, The Women of Genesis, 38-39.

38 Wenham, Genesis 16-50, 54. 
Turner suggests that Lot himself was not persuasive, thus "they might well think so because they fail to hear the ring of conviction in Lot's voice; for in the morning Lot shows that he himself does not take the angels' word seriously." ${ }^{39}$ We may never be sure, but Turner's suggestion is plausible.

\section{Ejection of Lot and Family from Sodom (19:15-22)}

This scene continues the scenic dialogic progression of this story, with snippets of narration introducing its direct discourses. At dawn, the angels charged Lot to get out of town. They now specifically asked him to leave with the family members present in the house namely his wife and two daughters (v. 15); yet Lot shilly-shallied (מהת), v. 16). Different suggestions have been made for his attitude, including being an indifferent self-serving person, ${ }^{40}$ loving the cities of the plains, ${ }^{41}$ and not believing God. ${ }^{42}$ One other option is the root meaning of מהת , which also incorporates the idea of panic or confusion (as seen from the noun form of it, מהומה). The proximate cause of Lot's separation from Abraham was his wealth; yet, as he leaves Sodom, he leaves with nothing. This could devastate anyone and throw him or her into confusion and panic. Perhaps this is one explanation for his hesitancy. ${ }^{43}$ Tired of his dithering, the angels grabbed him and his family and dragged them out of the city because of YHWH's mercies, to save them, with a warning not to look back.

Ejected from the city, the loquacious Lot (he speaks more often and longer than anyone else in this story) was not done yet; he must have the final word. When told to flee to the safety of the mountains, he blatantly told the angels that he could not and demanded that the little city of Zoar be spared for him because it is little. Here are a few salient things in this dialogue. Lot, who earlier addressed the angels as (term of respect for men, like "sirs"), now uses ("Lord," the address for deity). It is possible that YHWH reappeared and revealed himself to Lot, as the subsequent destruction of the city is attributed to him and not the angels. ${ }^{44}$

Besides, the disparity between Abraham and Lot is magnified here. Abraham's intercession for Sodom was anchored in justice (against collateral punishment of the righteous with wicked); for Lot, God must do right by Lot and spare Zoar; after all, it is small, as if size has anything to do with wrong-doing. Lot's self-serving demand does not refer to his family, but refers to himself three

39 Turner, Genesis, 84.

40 Pace, The Women of Genesis, 1-4, 38-39.

41 Bergen, Genesis, 88; Turner, Genesis,84; Von Rad, Genesis, 224.

42 This is manifested in Lot feeling more "more secure inside an evil city than outside of it with God" (Waltke and Fredericks, Genesis, 278.)

43 Cf. Speiser, Genesis, 143.

44 For others, the angels are proxies for YHWH. Von Rad states, "Lot too speaks directly to God in the messengers" (Genesis, 220). 
times (vv. 19-20). This stands in sharp relief to the angels, who each time they spoke or acted in favour of Lot's exit from the city included his family (vv. 12, 17). This is where Lot's distinction with the Sodomites vanishes; he, like them, focused on his desires rather than the clear word of God. Even this whimsical demand, YHWH granted (note the first-person pronominal suffixes in the verbs

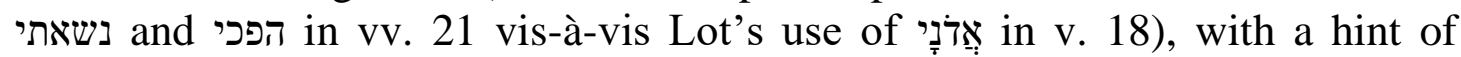
exasperation, as he urges Lot to flee since he was unable to do anything until Lot found safety (v. 22).

\section{Doomsday Is Here (vv. 23-26)}

This short episodic narration of the destruction of Sodom and its environs is the climax toward which the story builds. Lot, with all his shilly-shallying, finally reaches Zoar just as the morning sun was peeking over the horizon. At that instant, judgment descended on the offending cities. The narrator begins by saying YHWH rained upon Sodom and Gomorrah brimstone and fire from YHWH from heaven. This is not a clear statement. The Targumim (Pseud-J. and Jerusalem) interpret the first YHWH as "The Word of the Lord." We follow Wenham's suggestion that the construction is emphatic, hence, his rendition of v. 24 as "and the LORD rained brimstone and fire on Sodom and Gomorrah: it was from the LORD from the sky." 45 Just as in 19:4, the narrator laboured to specify who came to Lot's house, in 19:25, he enumerates the victims of the devastation. The narrator specifies that the cities, the whole plain, the habitants of the cities and vegetation were all gutted; and even Lot's wife (who disobeyed the order not to look back) perished with Sodom, as she calcified into a pillar of salt. ${ }^{46}$ What is most perplexing about the episode is that she was not mourned, neither by Lot nor by his daughters, who rather later assumed her role in their father's bed (19:30-38). This raises questions about the Lot's family dynamics.

\section{The God who remembers (vv. 27-29)}

The dénouement of our narrative ends where it began, with God and Abraham and with the destruction of Sodom in view (18:1, 16-33). The skilful narrator conveys Abraham's concern for Lot with an almost incoherent sentence, "Abraham rose in the morning to the place where he stood before YHWH" (v.

45 Wenham, Genesis 16-50, 35.

46 There are various suggestions as to why Lot's wife looked back. Lyons, "The Eternal Liminality of Lot," 9, submits that she was from Sodom, and if so then she must have been concerned for her family. Pace, The Women of Genesis, 39, blames it on Lot, who failed to pass the prohibition to his wife. This proposition has no basis in the text, which states that Lot and family were already on the road outside the city gate and everyone of them would have heard the prohibition. Von Rad, Genesis, 222, waxes pastoral in explaining that, "where God intervenes in a direct act on earth man cannot adopt the stance of a spectator (cf. at chs $2: 21 ; 15: 12$ ); and before divine judgment there is only the possibility of being smitten or of escaping, but no third alternative." 
27). This defective construction portrays the haste with which he went out to check the "headlines of the day." Once he got to the place, Abraham re-enacted what happened the previous day. The travellers had "looked down toward" Sodom. Abraham, likewise, stood at the same place and "looked down toward" (וישקפ עלדגני). The only difference is, while the travellers had focused on Sodom, the chief city of the region, the ongoing conflagration causes Abraham's eyes to pan across the entire region.

Like a perfect movie ending, the narrator leaves his readers with Abraham wondering, "Whatever happened to Lot!" The reader is privileged to know the ending of the story; Abraham only sees the columns of smoke rising across the span of the ill-fated region. However, Abraham's God is the God that remembers. As Abraham remembered the previous day's discussions, YHWH also, in covenantal loyalty, remembered Abraham and saved Lot-as irredeemable as Lot proved to be.

\section{G TOWARD A THEOLOGICO-ETHICAL APPROPRIATION}

Lot is a complex and conflicted character. It is little wonder that his assessment in contemporary literature is also so conflicted. On the one hand, he is thought of as having evolved "from a man who journeys to Canaan with Abraham and Sarah to a man who leads a corrupt existence in Sodom where he no longer can be categorized as one of the righteous." ${ }^{47}$ On the other hand, he is seen as "a warm, good person. Unlike the men of his city, he is shown to be a host who is willing to sacrifice all that is dear to him in order to protect his guests." ${ }^{48}$ The narrator's realistic portrayal of Lot shows him to be a man of like passions as we are. How true it is that often we could be so caring of outsiders and yet do unkind things to those closest to us! It means then that there a few things that we could take away from this story.

In every age, it is common for people to rant against tradition. For all its faults, tradition is a stabilising force in society. Like culture, of which it is a part, tradition changes. When those changes occur incrementally, they do not destabilise social equilibrium. However, rapid discontinuous changes are bound to precipitate catastrophic consequences. Lot chose to abandon tradition, beginning with his non-deference to his uncle. Once he set on that trail, he never retraced his steps until he was lost in oblivion.

Lot's severance with tradition involved breaking loose from his privileged particular origins, as one in proximity to YHWH's covenant relationship with

47 Pace, The Women of Genesis, 32.

48 Peleg, "Was Lot a Good Host?," 153. For a more nuanced portrayal of Lot, see Sarna, Understanding Genesis, 150. 
Abraham (a particular man for the universal ministry to the nations). On this, Lyons writes,

Rather Lot's story is that of a man who has rejected the ideology of the text in which he appears. By leaving Abraham with no heir and thus seemingly with no descendants, Lot denies the necessity for the particular altogether ... Lot's residence in Sodom symbolizes his choice to identify with that nation as a representative of the universal and his personal rejection of the deity's plan to bless the nations through Abraham. ${ }^{49}$

Uncertain of his place in the particular, Lot embraced the universal unreservedly, as he was tantalisingly enticed into the bowels of the urban (cosmopolitan) landscape, in spite of it dangers - a story that is being re-lived by many diaspora populations today. In our historic moment, with its accent on the global rather the local, diaspora populations must learn to keep their universalist aspirations in good tension with their particularity, which may be accepted in their host communities but never eliminated.

Lot's pursuit of the global rather than the local arose from his feelings of liminality. Nonetheless, his immersion in the universal did not mitigate his marginality, but rather accentuated it. It is tragically ironic that in Abraham's home where Lot was accepted, even though not as an heir, he felt too much like an outsider whereas in Sodom where he felt so much at home, he was reminded he was an outsider. He thus left home in search of a home; eventually, in Sodom, he felt at home. He probably married there, had children there, was going to marry them out there, but for the devastation of the city. However, when the chips were down, the Sodomites showed him that, even there, he was "other" (an immigrant) and not an insider. Though he pleaded for Zoar, on arriving there, his sense of alterity followed him and drove him to utter liminality in a cave. The commonest feature of patriarchal figures palpably missing in Lot's life is a relationship with the family deity, YHWH. This seems to be the real source of all marginality. The more disconnected people are with God, the more likely they are to suffer from the feeling of displacement.

As humans, we are products of our choices. William B. Irvine observes that all the choices we make "typically reflect our desires: we choose what, all things considered, we want." bring about breakdown in social order. This is a critical theme of our text. The theology of the Torah shows that homosexual desires of the men of Sodom were inordinate (just like those of the Benjaminites of Gibeah in Judg 19), and consequently precipitated the region's ruin, as it led to other vices, not the least

49 John Lyons, "The Eternal Liminality of Lot," 12.

50 William B. Irvine, On Desire: Why We Want What We Want (Oxford: Oxford University Press, 2006), 91. 
inhospitality and cruelty to the "other." Societies where morality is offensive and the aspiration to let desires of every kind have free reign need to beware least they self-destruct.

The injustices of Sodom generated cried for justice. YHWH sent his angels like a grand jury, which returned not just an indictment, but also a guilty sentence on Sodom, resulting in its terminal judgment. Nonetheless, even in Sodom, Lot stood up (even in his liminal space) as a voice for justice. From myriads of oppressed peoples globally, cries for justice are ascending to heaven, but it remains to be seen if heaven's ambassadors on earth will catch the pulse of God's heartbeat and rise up to be his advocates for justice on earth.

\section{H BIBLIOGRAPHY}

Barth, Karl. Anselm: Fides Quaerens Intellectum: Anselm's Proof in the Existence of God in the Context of His Theological Scheme. London: SCM Press, 1960.

Bergen, Dianne. Genesis: In the Beginning. Liturgical Press, 2013.

Brett, Mark G. Genesis. London: Routledge, 2000.

Calum Carmichael, "Legal and Ethical Reflections on Genesis 18 and 19." Pages 101111 in Universalism and Particularism at Sodom and Gomorrah: Essays in Memory of Ron Pirson. Edited by Diana Lipton. Atlanta: Society of Biblical Literature, 2012.

Carr, David M. Reading the Fractures of Genesis: Historical and Literary Approaches. Louisville: Westminster John Knox, 1996.

Childs, Brevard S. Old Testament in a Canonical Context. London: SCM, 1985.

Cotter, David W. Genesis. Collegeville: Liturgical Press, 2003.

Freedman, David Noel (ed.). The Anchor Bible. Garden City: Doubleday, 1964.

Gesenius, Wilhelm, Emil Kautzsch and Arthur Ernest Cowley. Gesenius' Hebrew Grammar. Oxford: Claredon Press, 1910.

Harper, Goshen. Legal Frictions: Law, Narrative, and Identity Politics in Biblical Israel. New York: Peter Lang, 2010.

Irvine, William B. On Desire: Why We Want What We Want. Oxford: Oxford University Press, 2006.

Levine, Nachman. "Sarah/Sodom: Birth, Destruction, and Synchronic Transaction." Journal for the Study of the Old Testament 31/2 (2006): 131-146.

Lyons, William John. "The Eternal Liminality of Lot: Paying the Price of Opposing the Particular in the Sodom Narrative." Pages 3-15 in Universalism and Particularism at Sodom and Gomorrah: Essays in Memory of Ron Pirson. Edited by Diana Lipton. Atlanta: Society of Biblical Literature, 2012.

Moberly, R. W. L. The Theology of the Book of Exodus. New York: Cambridge University Press, 2009.

Morschauser, Scott. "'Hospitality,' Hostiles and Hostages: On the Legal Background to Genesis 19.1-9."Journal for the Study of the Old Testament 27/4 (2003): 461-485.

Pace, Sharon Jeansonne. The Women of Genesis: From Sarah to Potiphar's Wife. Minneapolis: Fortress, 1990. 
Peleg, Yitzhak (Itzik) "Was Lot a Good Host? Was Lot Saved from Sodom as a Reward for His Hospitality?" Pages 129-156 in Universalism and Particularism at Sodom and Gomorrah: Essays in Memory of Ron Pirson. Edited by Diana Lipton. Atlanta: Society of Biblical Literature, 2012.

Sarna, Nahum M. Understanding Genesis. New York: Schoken Books, 1966.

Speiser, E.A. Genesis: Introduction, Translation, and Notes. The Anchor Bible. Garden City: Doubleday, 1964.

Steinberg, Naomi. Kinship and Marriage in Genesis: A Household Economics Perspective. Minneapolis: Augsburg Fortress, 1993.

Turner, Laurence A. Genesis. Second Edition. Sheffield: Sheffield Phoenix Press, 2009.

Tushima, Cephas T. A. The Fate of Saul's Progeny in the Reign of David. Portland: Pickwick, 2011.

. "The Paradigmatic Role of Genesis 3 for Reading Biblical Narratives about Desire." Unio cum Christo 5/1 (April 2019): 87-103.

Von Rad, Gerhard. Genesis: A Commentary. London: SCM Press, 1972.

Waltke, Bruce K. and Cathi J. Fredericks. Genesis: A Commentary. Grand Rapids: Zondervan, 2001.

Warner, Megan. "Keeping the Way of YHWH: Righteousness and Justice in Genesis 18-19." Pages 113-125 in Universalism and Particularism at Sodom and Gomorrah. Edited by Diana Lipton. Atlanta: Society of Biblical Literature, 2012.

Wenham, Gordon J. Genesis 16-50. Word Biblical Commentary. Vol. 2. Dallas: Word Books, 1974.

Rev. Prof. Cephas T. A. Tushima; E-mail: tushima.cephas@gmail.com; Affiliations: Biblical Studies Dept, Jos ECWA Theological Seminary (JETS), Nigeria; and Department of Biblical and Ancient Studies, University of South Africa, Faculty of Human Sciences, Pretoria, South Africa. Orcid \#: https://orcid.org/0000-0003-0923-1350 